\title{
CHRISTIAN SYMBOLISM OF DEATH IN THE WORKS OF REPRESENTATIVES OF RUSSIAN RELIGIOUS PHILOSOPHY
}

\author{
(C) Igor M. Grekov, Olga A. Orlenko \\ Ryazan State University, Ryazan, \\ Don State Technical University, Rostov-on-Don, Russian Federation \\ r.podol@365.rsu.edu.ru, osya8923@yandex.ru
}

The specificity and essential features of the Christian symbolism of death in Russian religious philosophers of the $19^{\text {th }}-20^{\text {th }}$ centuries are considered. It is noted that the low degree of elaboration of this topic creates the problem of translating Christian symbols in religious studies courses in modern Russian universities. The insufficient degree of development of such aspects of Christian symbolism as the establishment of the source of origin, the specificity of the image and the identification of the essential features of the Christian symbolism of death based on the study of the works of representatives of Russian religious philosophy is emphasized. The connection between the dual understanding of death that developed in Russian religious philosophy in the 19th-20th centuries and the specificity of the depiction of Christian symbols of death in religious art is revealed. The presence in Russian philosophy of both theological and psychological points of view on the interpretation of Christian symbols of death is noted. Based on the study of the works of L.P. Karsavin, N.A. Berdyaev, P.A. Florensky, S.N. Bulgakov, B.P. Vysheslavtsev, I.A. Ilyin and A.F. Losev, such Christian symbols of death as a cross, a solar eclipse, the head (skull) of Adam, a grain of wheat, an hourglass (time), a door, a flower are revealed. Examples of the embodiment of Christian symbols in religious art are given, it is concluded that the symbols of death in Russian religious philosophy are simultaneously symbols of resurrection.

Key words: God, Christian values, death, symbols of death, symbol of resurrection, image of death.

\section{[И.М. Греков, О.А. Орленко Христианская символика смерти в трудах представителей русской религиозной философии]}

Рассматривается специфика и сущностные черты христианской символики смерти в русских религиозных философров XIX-XX вв. Отмечается, что невысокая степень разработанности данной темы создает проблему трансляции христианских символов в учебных курсах религиоведческой направленности современных российских вузов. Подчеркивается недостаточная степень разработанности таких аспектов христианской символики, как установление источника происхождения, специфики изображения и выявления сущностных признаков христианской символики смерти на основе исследования трудов представителей русской религиозной философии. Раскрываются связь между двойственным пониманием смерти, сложившимся в русской религиозной философии в XIX-XX вВ., и спецификой изображения христианских символов смерти в религиозном искусстве. Отмечается наличие в русской философии как теологической, так и психологической точек зрения на интерпретацию христианских символов смерти. На основе исследования работ Л.П. Карсавина, Н.А. Бердяева, П.А. Флоренского, С.Н. Булгакова, Б.П. Вышеславцева, И.А. Ильина и А.Ф. Лосева, выявляется такие христианские символы смерти, как крест, солнечное затмение, голова (череп) Адама, пшеничное зерно, песочные часы (время), дверь, цветок. Приводятся примеры воплощения христианских символов в религиозном искусстве, сделан вывод, что символы смерти в русской религиозной фрилософии одновременно выступают символами воскрешения.

Ключевые слова: Бог, христианские ценности, смерть, символы смерти, символ воскресения, образ смерти.

Igor M. Grekov - Ph.D. in Philosophy, Ryazan State University, Ryazan, Russian Federation.

Olga A. Orlenko - Ph.D. in Philosophy, Don State Technical University, Rostov-on-Don, Russian Federation.

Греков Игорь Михайлович - кандидат философрских наук, Рязанский государственный университет, 2. Рязань, Российская Федерация.

Орленко Ольга Александровна - кандидат фрилософрских наук, Донской государственный технический университет, г. Ростов-на-Дону, Российская Федерация. 
Any religion, including Christianity, contains symbols that are understandable to its adherents, as well as scientists studying religious problems. Christian symbols are present in religious painting, architecture and sculpture, influencing the religious feelings of believers. The topic of studying Christian symbolism was repeatedly raised in the works of P.A. Florensky, L.P. Karsavin, I.A. Ilyin, S.N. Bulgakov, N.A. Berdyaev, B.P. Vysheslavtsev and A.F. Losev, whose life fell on the $19^{\text {th }}-20^{\text {th }}$ centuries. N.A. Berdyaev emphasized that "classical examples of symbolism are given by mystics and artists, not philosophers, in descriptions of spiritual experience, and not in teachings" [2], thus pointing to religious art as a true repository of religious symbols. Russian thinkers were especially interested in the study of Christian symbols of death, which was due to the religious and mystical nature of their philosophy and the revolutionary events in Russia at that time.

In modern Russian higher education, there is a problem of translating Christian symbols. It is expected that students should familiarize themselves with the content of this topic in the courses of religious studies, philosophy of religion, cultural studies and some other disciplines. However, many aspects of Christian symbolism still remain insufficiently studied in science for several reasons: firstly, in modern Russian society there is an unspoken ban on discussing the topic of death, and secondly, the experience of the mystical experience of death is difficult to express in language; thirdly, for a long time in the history of our country, the works of Russian thinkers containing information about Christian symbols were banned by the censorship; fourthly, in most sources devoted to Christian symbols, including the Christian symbols of death, scientists only single out a number of Christian symbols which are most often found in religious art. However, a number of such modern Russian authors as Hieromonk Iriney (Pikovsky), S. Bulanov, Yu. Pushchaev, carry out in their works the study of the cross as one of the most important Christian symbols of death.

Reflecting on the specifics of the Christian symbol, P.A. Florensky pointed out in his work: "Thus, the whole point is that the image of an object is not at all an object as an image, is not a copy of a thing, does not double the angle of the world, but points to the original as its symbol" [14, p. 79], emphasizing that Christian symbols should not be a copy of the transcendental world and God denoted through them, which would violate one of the main prohibitions in Christianity. According to the thinker, religious symbols have a historically stable character and are not a product of human imagination, their source is God, which, according to the philosopher, is proved by the fact that the same religious symbols are found in the culture of different peoples of the world. Another Russian thinker, A.F. Losev, considered the problem of determining the symbol to be one of the most important problems facing modern scientists. According to A.F. Losev, the concept of a symbol has not been purposefully studied in Soviet science for a long time, as together with some other concepts it was considered generally accepted: "What could be simpler than the fact that A indicates B and is its symbol?" [8, p. 247]. The thinker called religious symbols "the intuition of the possibilities contained in the present," thereby defining the essence of a religious symbol, indicating the existence of a true spiritual world in a temporary earthly world, and also noted such qualities of a religious symbol as sensibility, ideality and artistry. Discussing the types of religious symbols in various religions, the modern Russian philosopher and culturologist A.L. Dobrokhotov notes that "intense symbolic imagery" is a characteristic feature of Christianity, in contrast to other monotheistic religions, or rather, such currents as Orthodoxy and Catholicism. Thus, the Russian philosophers P.A. Florensky and A.F. Losev emphasized the transcendental origin of a religious symbol, defining a symbol as a sign designed to remind a person of the existence of an outside world into which he will pass at the end of his earthly life. The peculiarity of the religious symbol, in their opinion, was precisely that it had to indicate the existence of the transcendental world, and not create it anew. 
In religious art, we find a fairly large number of Christian symbols, among which the most common are the sun, lion, cross, star, burning bush, dove, crown of thorns, lamb, anchor, eagle, calf, angel. Another characteristic feature of the Christian symbol in religious art is its polysemy. The same biblical character or the same biblical event can be represented by different Christian symbols. Conversely, the same Christian symbol can denote different events from the Holy Scriptures, depending on the context of its use. So, according to A.F. Losev: "Unlike allegory, image, emblem, etc., the symbol is conceptually inexhaustible, since it "captures many deep connections" [9]. For example, symbols of Jesus Christ in religious art, according to B.P. Vysheslavtsev, are the baby, the cross, the star, the crown of thorns, the vine and the lamb. Speaking about the specifics of a religious symbol, A.F. Losev emphasized the complexity and depth of understanding of this term. The concept of a symbol, in the opinion of this thinker, is not reducible to any of its individual qualities, but includes the entire totality of these qualities, even despite the schematic representation of a religious symbol in art. One of the most common symbols of Jesus Christ in religious art is the sun: "The Lord Himself, as the source of all light, goodness and bliss, is figuratively called the Sun in Holy Scripture (Psalms LXXXIII, 12)" [1, p. 269].

Thus, Russian philosophers believed that the specificity of the invention of the Christian symbol lies in the simplicity and sketchiness of its invention. As signs of a religious symbol, philosophers called the historical stability of its existence and the ambiguity of its use.

However, in Russian philosophy there were attempts to interpret the Christian symbol from various points of view, so the Russian thinker B.P. Vyshe-Slavtsev wrote that: "plunging into the depths of our own subconsciousness, we find there a subterranean stratum of all layers of our life. This is an emotional-subconscious memory that stores everything and remembers everything, but from which the conscious-intellectual memory is able to extract only a little..." [4, p. 272], thereby referring us to the doctrine of the collective unconscious of the representative of the psychoanalytic direction of the philosophy of C. Jung, with whose work he was familiar. Psychological interpretations of Christian symbols can also be found in the works of P.A. Florensky.

But if the image of the sun in religious art, according to the representatives of Russian philosophy, symbolizes Jesus Christ, then the solar eclipse symbolizes His torment and death on the cross. A.F. Losev considered a symbolic solar eclipse during the funeral of Aksinya in the "Quiet Don" by M.A. Sholokhov. In the culture of different peoples, the night was recognized as a symbol of death and the end of life, and black meant mourning and grief, so the relatives of the deceased wore clothes of this color for his funeral. However, according to I.A. Ilyin and S.L. Frank to compare death with the beginning of evil and darkness is not correct, since death in Russian philosophy is of a dual nature. On the one hand, it is a punishment for the sin committed by the first people, on the other hand, it entails posthumous resurrection as the highest value for a believing Christian. In the book of Ecclesiastes, we find confirmation of a positive attitude towards natural death in Christianity: "A name is better than good butter, and the day of death is better than the day of his birth" (7: 1). Therefore, a solar eclipse in religious art symbolizes both death and the Resurrection of Jesus Christ at the same time. The image of the sun was used in the design of the tombstones of the dead, as a reminder of the posthumous resurrection.

One of the main Christian symbols of death and resurrection in Russian philosophy was the image of the cross. Emphasizing the importance of this symbol for believing Christians, N.A. Berdyaev wrote that the death of Jesus Christ on the cross and the Resurrection are the main events of the New Testament, and the cross itself is a symbol that believing Christians wear on their bodies: the image of Christ Crucified and Humiliated acquires the highest meaning, the Cross becomes sweet, sweetest, the Gospel teaching is the verb of 
eternal life..." [5, p. 5]. The resurrection of Jesus was the first example of the victory over death by inspiring Christians.

In addition to the solar eclipse and the cross, a symbol of death and resurrection in religious art, reflected in the works of representatives of Russian religious thought, was the image of the head (skull) of Adam, located at the feet of Jesus Christ, on the iconographic or sculptural image of his crucifixion. The book of Genesis speaks of the punishment that must follow in case of violation of the prohibition established by God "on the day on which you eat of it, you will die by death" (Gen. 2:17). But disobeying God, the first people tasted the forbidden fruit and became mortal. The systematizer of theological knowledge, St. Luka Voyno-Yasenetsky, interpreted this symbol as follows: "Because of Adam we all die, from Adam we are all infected with sin leading to death, and only with help of Christ we will all come to life: only Christ redeemed us with His blood from the original sin of our ancestors" [12, p. 98]. Russian religious thinker L.P. Karsavin wrote in his Poem about Death: "But the fact of the matter is that the sins of others are not alien to me, but my own. All of us, although each in his own way, add to our "want" the same, imperceptible, like a thin thread, "not". In him, even in him, we are all one Adam" [7]. We also find the mention of the head (skull) of Adam as a symbol of death in the Sophiology of Death by Father Sergius Bulgakov: "Adam's humanity in Christ, of course, could, by the power of union with the Divine, appear free from the inner necessity of death and remain immortal by the power of this, but it was free to succumb to violent death, from crucifixion, as the death of the Lord on the cross testifies to" $[11$, p. 22].

Another symbol of death in religious art, according to Russian thinkers, is a grain of wheat. In the work "Death is a friend and an enemy. The disciple Paul's Decision" B.P. Vysheslavtsev interpreted this symbol as the emergence of a new, more perfect form of existence through the through the end of the old one. A grain that has fallen into the ground soon gives rise to a sprout, which by its appearance terminates the existence of the grain, which earlier gave rise to the existence of a sprout. Like a grain, death opens up before a person the possibility of continuing life in the afterlife: "This antinomy has not yet been completely resolved by theology and has not been realized by ordinary church consciousness. But in the $15^{\text {th }}$ chapter, the disciple Paul outlines its solution in the words: "it will not come to life unless it dies" and "it is sown in corruption, it rises in incorruption", "a spiritual body is sown, a spiritual body is raised." The meaning of Christianity as a religion consists in gaining eternal life through the passage of death. P.A. Florensky spoke about the grain of wheat as a symbol of death. He in his work "Iconostasis" said: "One can say that the more ontological the vision, the more universal the form in which it will be expressed, just as the sacred words about the most mysterious are the simplest: father and son, birth, rotting and sprouting grain..." [13]. In addition to B.P. Vysheslavtsev and P.A. Florensky "grain of wheat" acted as a symbol of death in the works of S.L. Franc. This thinker interpreted the grain of wheat as "...effectively and vital overcoming of world nonsense with the true meaning of life" [17]. A grain of wheat that has fallen into the ground is a "sacrifice" that must be made for the sake of human rebirth. According to A.F. Losev, image of grain symbolizes the "new message".

The hourglass (time) is a symbol of the finiteness of a person, their perishability and death in religious art. In the work "Mystic of Rainer Maria Rilke" S.L. Frank pointed out that the entire history of mankind is something other than the "rebellion of the kingdom of time." "Time is "the deepest pain "of God, and He put in it" a woman, abundant Death, "a terrible bacchanalia of cities, the madness of kings" [16]. Exploring the inscriptions on ancient Roman tombstones, P.A. Florensky concluded that the ancient Romans considered the terms time and death synonymous: "do not grieve, mother, about my death, Time wanted it, it was my time" [15, p. 533].

In the works of I.A. Ilyin and S.N. Bulgakov's Christian symbol of death is the door. So in his article "On Death and Immortality," I.A. Ilyin compared death with the "great door": "it 
is still some kind of mysterious, given to us by God "measure of all things" or all human affairs. We need it not only as a pattern-maker or as a great door for the final departure; we need it first of all in life itself and for life itself" [6, p. 87]. S.N. Talking about death, S.N. Bulgakov also called the transition of the soul of the deceased into the afterlife the opening of the door: "Only death itself can open the door to this area" [3].

Another symbol of death in Christianity is a flower. The image of a rose in religious art quite often symbolizes death. The presentation of flowers can be seen as a symbol of birth or death, depending on the context. Here again we meet with such a characteristic of the Christian symbol as its polysemy. In various images, a rose can symbolize completely opposite concepts. The image of a rose as a symbol of death was used by L.P. Krasavin. A.F. Losev said that the image of plants, in particular, cypress or juniper, was used by the Romans as symbols of death or associated funeral and grief. But the cypress as a plant taken by itself is in no way connected by itself with the idea of death. "Consequently, its substrate is not at all the death of a person, but is a living plant tissue" [10].

In the Russian religious philosophy of the $19^{\text {th }}-20^{\text {th }}$ centuries, not only the symbols of death were reflected, but also the collective image of death, obtained on the basis of the mystical experience of the dying and the image of death, which received its design in medieval art in which death was depicted as a skeleton chained in armor with a sword or other melee weapons. P.A. Florensky and S.N. Bulgakov described in their writings the mystical image of death, in which she appeared in the form of a transcendental being with various attributes, and also named a number of people between life and death, to whom death appeared in a similar image.

Thus, Russian religious thinkers reasoned in their writings about the origin and essential features of Christian symbols. They attached great importance to the need to study Christian symbols for all people, tried to interpret them from theological and psychological points of view. Representatives of Russian philosophy emphasized the supernatural nature of the origin of Christian symbols, pointed out that their main purpose is to remind believing Christians about God and the true transcendental world. In their works, they named a number of such essential features of the Christian symbol as: polysemy, sensuality, historical stability, impossibility of rational explanation, independence from empirical experience. The specificity of the depiction of Christian symbols in the works of Russian thinkers was declared to be the simplicity and sketchiness of the image, which was associated with the prohibition established in Christianity on the creation of a copy of God. Death in Russian philosophy was portrayed not only with the help of symbols, but also figuratively, thanks to the stories of people who are between life and death and the image of death, which developed in European medieval art under the influence of wars, plagues and hunger. As Christian symbols of death in religious art, Russian thinkers called a solar eclipse, a cross, the head (skull) of Adam, a grain of wheat, an hourglass (time), a door, a flower. A feature of the Christian symbols of death in Russian philosophy was the recognition of them as symbols of resurrection, which was explained by a special attitude towards death as a transition from earthly life to the grave. The results obtained in the course of studying the works of Russian thinkers can be included in the training courses on religious topics in universities.

\section{Лumepamypa}

1. Архимандрит Никифор (Бажанов) Солнечное затмение // Иллюстрированная библейская энциклопедия. М.: ЭКСМО, 2016. С. 269.

2. Бердяев H.A. Символ. Миф. Догма. Философия Свободного Духа. URL: https://www.litres.ru/nikolay-berdyaev/filosofiya-svobodnogo-duha/chitat-onlayn/ (Дата обращения: 07.03.2021). 
3. Булгаков С.H. Загробная жизнь. URL: https://azbyka.ru/zhizn-za-grobom. (Дата обращения: 07.03.2021).

4. Вышеславцев Б.П. Бессмертие, перевоплощение и воскресение // Вечное в русской философрии. Нью-Йорк: Издательство имени Чехова, 1955. 298 с.

5. Ильин В.Н. Запечатанный гроб. Пасха Нетления: объяснение богослужений Страстной недели и Пасхи. Париж: YMCA-PRESS, 1926. 125 с.

6. Ильин И.А. Поющее сердце. Книга тихих созерцаний. М.: Даръ, 2006. 320 с.

7. Карсавин Л.П. Поэма о смерти. URL: http://www.vispir.narod.ru/kars6.htm. (Дата обращения: 03.07.2021).

8. Лосев А.Ф. Логика символики мифологии. Культура. URL: https://www.gumer.info/bibliotek_Buks/Culture/Los_PrSimv/10.php (Дата обращения: 23.02.2021).

9. Лосев A. Определение понятия символа. URL: https://www.gumer.info/bibliotek_Buks/Culture/Los_PrSimv/10.php. (Дата обращения: 07.03.2021).

10.Лосев А.Ф. Проблема символизма и реалистического искусства. URL: https://www.litmir.me/br/?b=82418\&p=11 (Дата обращения: 07.03.2021).

11. Протоиерей Сергий Булгаков Софиология смерти // Вестник русского христианского движения. 1978. № 127. С. 18-32.

12. Святитель Лука Крымский (Войно-Ясенецкий) О первородном грехе // Избранные творения. М.: Сибирская Благозвонница, 2010. - 437 с.

13. Флоренский П.А. Иконостас: Очерки в 4-х томах. Том 2. M., 1996. URL: https://www.torchinov.com. (Дата обращения: 23.03.2021).

14. Флоренский П.А. Обратная перспектива: Очерки в 4-т. Т. 3 (1). М.: Мысль, 2000. С. 46-104.

15. Флоренский П.А. Столп и утверждение истины: Опыт православной теодицеи. Очерки: в 2 т. Том 1. (2). М.: Правда, 1996. 640 с.

16. Франк С. Л. Мистика Райнера Марии Рильке // Путь. 1928. № 12. С. 65-66.

17.Франк С.Л. Оправдание веры // Смысл жизни. Берлин, 1925. URL: http://lib.ru/HRISTIAN/FRANK_S_L/smysl.txt. (Дата обращения: 07.03.2021).

\section{References}

1. Arkhimandrit Nikifor (Bazhanov) Solnechnoye zatmeniye. Illyustrirovannaya bibleyskaya entsiklopediya [Solar eclipse. Illustrated Bible Encyclopedia]. Moscow: EKSMO. 2016. 269 p. (in Russian).

2. Berdyayev N.A. Simvol. Mif. Dogma. Filosofiya Svobodnogo Dukha [Symbol. Myth. Dogma. The Philosophy of Free Spirit]. Available at: https://www.litres.ru/nikolay-berdyaev/filosofiya-svobodnogo-duha/chitat-onlayn/ (accessed 7 March 2021) (in Russian).

3. Bulgakov S.N. Zagrobnaya zhizn [Afterlife]. Available at: https://azbyka.ru/zhizn-zagrobom (accessed 7 March 2021) (in Russian).

4. Vysheslavtsev B.P. Bessmertiye, perevoploshcheniye i voskreseniye [Immortality, reincarnation and resurrection]. Vechnoye v russkoy filosofii. New-York: Izdatelstvo imeni Chekhova, 1955. 298 p. (in Russian).

5. Ilyin V.N. Zapechatannyy grob. Paskha Netleniya: obyasneniye bogosluzheniy Strastnoy nedeli i Paskhi [The sealed coffin. Passover of Incorruption: An Explanation of the Divine Services of the Holy Week and Passover]. Paris: YMCA-PRESS, 1926. 125 p. (in Russian). 
6. Ilyin I.A. Poyushcheye serdtse. Kniga tikhikh sozertsaniy [Singing heart. The book of quiet contemplation]. Moscow: Dar. 2006. 320 p. (in Russian).

7. Karsavin L.P. Poema 0 smerti [A poem about death]. Available at: http://www.vispir.narod.ru/kars6.htm. (accessed 3 July 2021) (in Russian).

8. Losev A.F. Logika simvoliki mifologii. Kultura [The logic of the symbolism of mythology. Culture]. Available at: https://www.gumer.info/bibliotek_Buks/ Culture/Los_PrSimv/10.php (accessed 23 February 2021) (in Russian).

9. Losev A. Opredeleniye ponyatiya simvola [Definition of the concept of the symbol]. Available at: https://www.gumer.info/bibliotek_Buks/Culture/Los_PrSimv/10.php. (accessed 7 March 2021) (in Russian).

10. Losev A.F. Problema simvolizma i realisticheskogo iskusstva [The problem of symbolism and realistic art]. Available at: https://www.litmir.me/br/?b=82418\&p=11 (accessed 7 March 2021) (in Russian).

11. Protoiyerey Sergiy Bulgakov Sofiologiya smerti [Sophiology of Death]. Vestnik russkogo khristianskogo dvizheniya. 1978. No. 127. pp. 18-32 (in Russian).

12. Svyatitel Luka Krymskiy (Voyno-Yasenetskiy) O pervorodnom grekhe [On original sin] Izbrannyye tvoreniya. Moscow: Sibirskaya Blagozvonnitsa, 2010. 437 p. (in Russian).

13. Florensky P.A. Ikonostas: Ocherki v 4-kh tomakh [Iconostasis: Essays in 4 volumes]. V. 2. Moscow, 1996. Available at: https://www.torchinov.com (accessed 23 February 2021) (in Russian).

14. Florensky P.A. Obratnaya perspektiva: Ocherki v 4-t [Reverse Perspective: Essays in 4 Volumes]. V. 3 (1). Moscow: Mysl. 2000. pp. 46-104 (in Russian).

15. Florensky P.A. Stolp i utverzhdeniye istiny: Opyt pravoslavnoy teoditsei [The Pillar and Statement of Truth: The Experience of Orthodox Theodicy]. Essays: in 2 volumes. Volume 1 (2). Moscow: Pravda, 1996. 640 p. (in Russian).

16. Frank S.L. Mistika Raynera Marii Rilke [Rainer Maria Rilke's Mystic]. Put. 1928. No. 12. pp. 65-66 (in Russian).

17. Frank S.L. Opravdaniye very [Justification of Faith]. Smysl zhizni. Berlin. 1925. Available at: http://lib.ru/HRISTIAN/FRANK_S_L/smysl.txt (accessed 7 March 2021) (in Russian). 